\title{
THE HONORIFICS EXPRESSIONS IN INDIGENOUS LANGUAGE OF JAVA ISLAND ETHNICS WITH RELEVANCE INTO ENGLISH
}

\author{
Mochamad Nuruz Zaman[1], Mangatur Rudolf Nababan[2], Djatmika[3]
}

[1] azzam.nuruzzaman93@student.uns.ac.id, [2] amantaradja@yahoo.com, [3] djatmika@uns.ac.id Universitas Sebelas Maret, Indonesia

\begin{abstract}
This research is a sociolinguistics study by examining greetings and verbs that accommodate honorific expressions in addressee, referent, bystander, and entire honorifics categories. This study also focuses on novel drama genre and women's struggle in upholding justice by Okky Madasari, Entrok, 86, Maryam, Pasung Jiwa, and Kerumunan Terakhir. The used descriptive qualitative method is analysis model of Spradley known as ethnography methodology that is highly domain analysis of data sources. Addressee honorifics well integrates into all kinds of them; they are in a kinship of family and relative, second personal pronoun, non-kinship of general society, occupational, religion, and local custom, as well as a verb.

Furthermore, referent honorifics develops in almost kinds of them, and they are kinship of family, second personal pronoun, non-kinship of general society, occupational, religion, and local custom, as well as a verb. While by-stander honorifics flies in a half part of them, they are kinship of relative, third personal pronoun, nonkinship of general society, occupational, religion, and local custom. However, absolute honorifics consistently synergies with one part of them, it is religion.
\end{abstract}

Keywords: greeting, verb, honorifics expression, translation, Okky Madasary novel

\section{INTRODUCTION}

Language contact is seen as a social system, communication pattern, and community culture by sociolinguistics. According to Pateda (1987, p. 57), Sociolinguistics highlights the whole issue relating to social organization and language behavior, and also do not includes only language usage, but also language attitudes, behavior toward language and language usage.

In sociolinguistic studies, there is a possibility people start from a social problem then associate it with language, but it can also be the opposite, starting from language then associating it with social phenomena. Therefore, sociolinguistics language research always takes more the use of language in the society that is influenced by social factors, including social status, education level, age, ethnicity, religion, and gender. It is also affected by situational factors such as who the speaker is, what the language is, to whom, when, where, and about what issues from the language context or the use of the language.

Meanwhile, Halliday (1992) mentioned sociolinguistics as an institutional linguist, related to language linkage with people who applied the language. The use of language might have various aspects, such as number, attitude, customs, and culture. Furthermore, there is an affirmation that language is part of a culture, and language is not an independent one. The use of language will also cause language variation, such as forms of parts or variations of language in the general pattern of the mother language.

The use of mother language, Javanese, becomes the mother tongue as well as the daily language to communicate. The existence of this language as well as other regional languages in Indonesia begins to shift to the Indonesian and foreign language terms that have been considered more acceptable. However, the use of Javanese is not wholly abandoned by the native speakers. There are a 
group of speakers who remain faithful in Javanese as traditional art performances, film industry, to academic level.

Javanese speech has three levels. The three levels of speech widely and generally serve as a means of communication within the Javanese. The level of speech is viewed regarding manners of language, indicating the difference between speakers with said partners. The level is, the speech level of ngoko states the level of courtesy and low social status, the speech level of madya, declares the level of courtesy and social status, the level of speech manners, states the level of courtesy and high social status. Based on the description, it can be generally concluded that there are some speech-level functions in Javanese language that indicate the nature of the relationship between the speaker and the speech partner, indicating the level of respect or the level of decency, indicating the difference in social status, indicating the ongoing situation (Moeliono, 1985).

Indonesian courtesy also considers the place, especially in spoken Indonesian, such as family environment, one of respect for language, education environment, form of communication and form of respect, cultural environment, as a distinctive communication means in a Javanese performance, religious environment, in marriage and khutbah, work environment, in unofficial situations sometimes also use Indonesian language, and community environment (Djatmika, 2015)

Research on Javanese language speech still emphasizes one influence of factors namely the difference of social status, tend not to pay attention to what language to speak or to whom the speech is delivered. It proved if there was no linguistic variation in levels according to the supposed speech. The speech should always maintain the rules and variations of language, but it was not shown in the studied analysis (Indrayanto, 2010; Sasangka, 2009; Prayogo et al., 2015; Munawaroh et al., 2015).

The analyzed concept of the utterances has not found concerning how the speeches are delivered, and the possible structures of the language used, even though the two concepts are very relevant to form an appropriate speech-level study (Pratiwi et al., 2009, Purwitosari, 2010). There are also many overlaps between what language it was spoken and what structural possibilities in the language used because there was no description of the speech of the relevance of the topic of conversation. Besides, it has no detailed speech description that became the core problem.

There was also a shift in descriptions that can result in the level error (Prayogo et al., 2015; Suprapto: 2013). In the end, they also have not included a speech mechanism with a description of the situation and an explanation of the factors that influence it. This overlapping understanding is also reinforced by the lack of an explanation of the situation of each level of speech. In the end, they also have not examined how the utterances constructed to the level of speech with appropriate study, which in turn can also be used to analyze more deeply about the utterance of the representation of honorifics.

This research is a sociolinguistics study by examining greetings and verbs that accommodate honorific expressions in addressee, referent, bystander, and entire honorifics categories. This study also focuses on novel drama genre and women's struggle in upholding justice Okky Madasari's work Entrok, 86, Maryam, Pasung Jiwa, and Kerumunan Terakhir. Furthermore, the detailed research question is formulated "how greetings and verbs accommodate honorific expression in the novel by Okky Madasari?"

\section{LITERATURE REVIEW}

\section{Greetings}

Pateda (1987, p. 69) suggested that greeting was a word or phrase using the speech system. The existence of this greeting system also influenced the used words and the way of disclosure which able to show the relationship and the social role among speech implications. Then, the intended concept of the greeting in this paper differs from the opinion of Kridalaksana (1978, p.15) argued that the greeting system as a system that links gather as a set of used words or phrases to call and summon offenders in a language event. The perpetrators consist of actor 1 (speakers), actor 2 (who talked to or partners say), and actor 3 (in the discussion).

The described lingual form in this discussion refers to the opinions of ErvinTripp (1973, p.225) and Fasold (1994, pp.12- 
15). According to them, the form and use of the greeting (forms of address) based on kinship, personal pronoun, nobility and nonkinship

1) Greeting of kinship

Kinship greeting is a greeting related to blood relations and marriage affiliation. Blood relations are called kinship of family, while marriage is called kinship of relative (Aslinda et al., 2000, p.7-12). Braun (1988, p.9) kinship terms associated with blood relations and heredity.

2) Greeting of nobility title

The stratification of society was divided into two groups, namely the nobility (prestigious) and ordinary people. Both of these groups in the life of society is not such visible difference also in the understanding of social manners. It is just that the difference between the two groups is the title in front of the name owned by the nobility.

3) Greeting of the personal pronoun

Personal pronoun could be used to greet someone or point to someone (Kridalaksana, 1974, p.17). The first personal pronoun is used for selfappointment (speaker), the second personal pronoun refers to the addressed person, and the third personal pronoun refers to the third person (the person in question).

4) Greeting of non-kinship

a) Non-kinship of general society

The greeting in the community is a used word to greet people who have no family relationship. It is also distinguished into greetings for older people, younger people, greeting for the same age, and for the unknown politely. As an example of a used greeting to greet people of the same age as a sibling, the greeting is Kak, Kang, Mas, Mbak and so on.

b) Non-kinship of occupational

The greeting in the profession or position is a greeting word that binds elements of language, which marks the difference in the structure and role of participation in the communication positions held in person.

c) Non-kinship of religion
The word religious greeting is a word used to greet people who are in a religious atmosphere, such as a mosque or other religious meetings. In line with the above understanding, saying that the word religious greeting is a greeting using to greet people who are professing and working in religion.

d) Non-kinship of local custom

This greeting form is inherited from generation to generation. The habits in question are the norms of tangible rules and the behaviors that apply in a community that is used for generations

\section{Verbs}

Verbs were central in clauses, meaning that all the other constituents are analyzed concerning the verb (Cook, 1989, p.153). The central meaning in verbs meaning firstly determined the existence of various structures of construction in the language in question and its changes (Sudaryanto, 1983, p.6). Simultaneously Chafe (1970, pp. 96-97); Kaswanti-Purwo (1989, p. 16); Cook (1989, p. 39 ), the verb determined what (nominal) category it stands for, what the noun relation was to it, and how it was semantically defined. It is the verb that determines the presence of a confident companion in the clause and together with the verb forms the relevant clause

\section{Honorifics Expression}

Yatim (1983, p. 10) explained that honorifics were the used linguistic forms to express respect in psychological and cultural rules. Kridalaksana (2008, p. 85) defined honorifics as a lingual form to express a respectable, which is a particular language was used to greet others. The lingual form in question could be a complex grammatical rule such as in Japanese that is marked by affixation. Meanwhile, according to KBBI, honorifics are concerned with the use of honorific expressions in the language to address specific people.

Based on some of the above definition, honorifics form can be stated as a form to declare the attitude of decency with the aim to respect the other person. Furthermore, Brown and Levinson (1978) made it clear that in any communication carried out by participants 
that it was not only to convey a message, but more than, that was to communicate, and also maintain mutual social relationships between speakers and partners. For example, Wardaugh (1986, p. 267) exemplified honorifics in the Javanese language. For example, for the word 'eat' can be realized with the word 'dhahar' or 'nedha' depending on whom the opponent was talking.

From the above definitions, it can be concluded that honorifics is associated with respect for others expressed through polite speech. Brown and Levinson (1978) added that honorifics is a system. It means that honorifics have subsystems or derivative categories below them.

Table 1. Speech Level of Nominal or Verb in Java, Indonesian, and English

\begin{tabular}{|c|c|c|c|}
\hline \multirow[t]{2}{*}{ Speech Level } & \multicolumn{3}{|c|}{ Language } \\
\hline & $\begin{array}{c}\text { Indonesia } \\
\mathrm{n}\end{array}$ & Java* & $\begin{array}{c}\text { Englis } \\
\mathrm{h}\end{array}$ \\
\hline High/Inggil* & $\begin{array}{l}\text {.... ke } \\
\text { belakang. }\end{array}$ & $\begin{array}{l}\text { Panjenenga } \\
n^{*}\end{array}$ & $\begin{array}{l}\text { Would } \\
\text { you } \\
\text { like to } \\
\text {... }\end{array}$ \\
\hline $\begin{array}{l}\text { Medium/Alu } \\
S^{*}\end{array}$ & $\begin{array}{ll}\ldots . . & k e \\
\text { kamar } & \\
\text { mandi }\end{array}$ & Sampean* & $\begin{array}{l}\text { please } \\
!\end{array}$ \\
\hline Low/Ngoko & $\begin{array}{ll}\ldots & k e \\
\text { toilet } \\
W C\end{array}$ & Kowe* & ...!! \\
\hline
\end{tabular}

*: only for nominal or verb in Javanese term

\section{Previous Study}

In relevant research related to honorific expression entitle "Saat Kesopanan Melintas Batas: Ulasan Teks Terjemahan Multi Bahasa dari Perspektif Sosiopragmatik" explains the change of modesty of Javanese language when realized in Indonesian and English (Khristanto, 2016). The similar study is presented entitled "The Acceptable Indigenous and Foreign Language to the Acceptable Indonesian Language Shifting: Sociolinguistics Case Study on UNS Print and Copy Area Overviewed within Translation Studies" which reveals the phenomenon of Javanese and Indonesian usage (Zaman et al., 2017). The journal entitled "Honorific Expressions in Arabic and English concerning other Languages" identifies the points of similarity and difference between honorifics in Modern Standard Arabic and English on the structure.
The study provides a brief explanation of the term honor and how the expression of honor is realized in both languages.

\section{RESEARCH METHOD}

The research design is descriptive qualitative in the form of embedded research namely linguistics contents focus on Sociolinguistics. Lincoln and Guba (1985) via Santosa (2017: 47) defines research location as determined focus boundary; it means "research limitation based on focus or object." Spradley (1980) via Santosa (2017: 48) states that research location must have main elements, they are setting, participant, and event. The setting is "Entrok, 86, Maryam, Pasung Jiwa, and Kerumunan Terakhir" novel by Okky Madasari, the participant is the actor and actress dealing with the novel, and the event is the effort of a woman in gender equality. Sources of data are "Entrok, 86, Maryam, Pasung Jiwa, and Kerumunan Terakhir" novel. The sampling is criterionbased sampling

Data collection technique is documentary (bibliography study) that applied in content analysis, Yin (via Sutopo, 2002, p. 69) states the techniques of studying document is a way to find the findings out dealing with research question and goal. The technique as follows: comprehending the context, finding out the greetings and verbs, integrating them into honorifics expression and analyzing those chosen words. Triangulation technique is the data source and method triangulation. The used descriptive method is the analysis model of Spradley (1980) known as ethnography methodology that is highly domain analysis. Categorization is conducted to see the symptoms of uniqueness in each culture or domain category so that the symptoms can be well mapped.

\section{FINDINGS \& DISCUSSION}

Comrie (1976) stated three honorifics expression systems based on for whom it was intended. Those categories were addressee, referent, and by-stander honorifics. First, addressee honorifics highly focused on the direct relationship between speaker and hearer. Second, referent honorifics was well known as a subject, focusing on the speaker 
and subject of utterances. Third, honorifics expression of speaker and audience, namely by-stander (via Brown \& Levinson, 1978)

Furthermore, Levinson (1983: 90-91) delivered honorifics expressions became two primary systems. The first system was called "relational," regarding with deictic social information. On that system, there were three sub-classifications to differ the deictic entity; they are addressee honorifics, referent honorifics, and by-stander honorifics. Meanwhile, other sub-classification related to interactor relationship and venerability pattern, it was highly noted as absolute honorifics.

\section{a. Addressee honorifics}

Brown and Levinson (1987: 276) stated that the honorifics receiver was people who directly involved in their interactions. Sifinaou (1992: 57) added it expressed the homage to intended person by well selecting the specific referent of language principles, either greeting or verb, to reach polite communication. The interaction was patterned below:

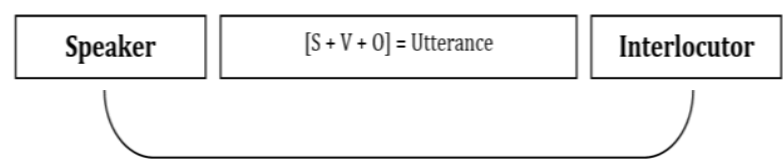

Figure 1. Interaction pattern of addressee honorifics (Adapted from Lee \& Ramsey, 2000)

1. Addressee honorifics of kinship

a) Addressee honorifics of family kinship

Source : "Aku kuat, Mbok. Lha text wong kita tiap pulang dari pasar juga nggendong goni. Malah jaraknya jauh, naik turun"

Target : "I'm strong Mbok. We text always carry heavy sacks when we come back from the market, plus the road is long and hilly."

It shows "Mbok" politely delivered by her daughter as a direct greeting equal with mother since then. Its chosen word gives a stereotype that this utterance happened in the '80s. Speaker and interlocutor are families, so it well integrates among them to honorifics term. Based on KBBI, Mbok is the Javanese language for greeting woman parent, mother.

b) Addressee honorifics of relative kinship

Source : "Aku tidak punya text Bapak, Bulik," jawabku getar.

Target : "I don't have a father, text Bulik." I said, trembling.

It shows a relationship among them; they are niece and her aunt. The term "Bulik" is equivalent to an aunt. She greets her by delivering "bulik" because it presents marital kinship. Based on Javanese culture, Bulik is abbreviation from "Ibu Cilik," the young sister of a mother.

2. Addressee honorifics of personal pronoun

Source : Suara seseorang text mengejutkan kami. "Kami mau menggeledah rumah. Saudara pemilik rumah?"

Target : The sound of another text person startled us. "We're here to search this house. Are you the owner?"

It shows second personal pronoun; it is addressed to an interlocutor. The chosen word "saudara" is politely stated to appreciate someone in the first meeting. To make the situation right, the speaker delivers it by choosing the appropriate word because he is a policeman. So, the delivered word of him must be the whole attitude. Therefore, his whole attitude of chosen word presents as an honorifics term.

3. Addressee honorifics of non-kinship

a) Addressee honorifics of general society

Source : "Ada kerjaan nggak, text $\underline{\text { u" }}$ " tanya Simbok 


\begin{tabular}{lll} 
& \multicolumn{2}{c}{ pada perempuan } \\
& penjual singkong \\
Target $:$ & "is there a job, \\
text & ma'am," & Simbok \\
& asked one of the \\
& women & selling \\
& cassavas
\end{tabular}

It shows market as location. Indonesian culture is presented as a greeting to the oldest woman, namely "Yu." Based on KBBI, it is same as mbakyu, yayu, older sister. Its chosen word is delivered to grow particular mean such as looking for the job, appreciating other, and so on. Here, it is applied for proposing herself to looking for a job. $Y u$ is a special greeting among woman in the market. Thus it has been culture for general society.

b) Addressee honorifics of occupational

Source : "Huss, Ni! Maaf Pak text $\underline{\mathrm{RT}}$, memang Marni nggak ngerti apa-apa soal keamanan. Dia tahunya Cuma bakulan di pasar," Bapak memotong jawaban Ibu.

Target : "Shush, Ni! I'm sorry, text chief, but Marni doesn't understand anything about security. All she knows is market trading," Father cut short Mother's response.

It shows a greeting for a man who works as a village leader, namely Pak RT. Additional Pak after RT is applied as an honorifics culture in Java Island although the interlocutor, of course, has a name, it is highly polite adding Pak or Mister for a person in charges like the chief or a leader in the village.

c) Addressee honorifics of religion Source : "Pak Kyai, pesantren text itu isinya orang-
orang agama to,"
Target : "Look here, kyai, an text Islamic school is filled with religious people, right."

It show greeting for the eldest leader in Islamics boarding school or cottage. Kyai is absorptivity of Arabic for respecting the Islamic teacher or expert teacher in Islam. Its honorifics is intended to the identity of the meant person.

d) Addressee honorifics of local custom

Source : Aku naik ke tempat text tidur dan langsung memeluk erat tubuh Maera sambil berseru, "Haiii, $\underline{\mathrm{Cah}}$ Ayu."

Target : I climbed onto the text bed and immediately hugged Maera's body tight as I shouted, "Hi, Miss Ayu."

It shows Javanese culture to greet his or her daughter by saying it, which means beautiful girls. Cah is bocah, generally has a meaning like a child and Ayu is female. Cah Ayu is a female child of Javanese culture.

4. Addressee honorifics of verbs

Source : "Nyuwun supaya jadi text orang pintar. Bisa jadi pegawai" kata Ibu.

Target : "Pray to be a clever text person. To be able to get a job," she said.

It shows a request to the God by choosing "nyuwun" has a meaning a pray in order to make life better.

\section{b. Referent honorifics}

Referent honorifics was meant as contact of interactor (speaker and hearer) and someone which was being spoken (referent). The homage was gone to someone as a subject in the utterance either as greeting and verbs. Lee \& Ramsey (2000) mentioned that its form as a subject. A term for heightening person 
that was being utterance subject. The direct interaction was patterned below:

Speaker $[\underline{\mathbf{S}}+\underline{\mathbf{V}}+0]=$ Utterance

Figure 2. Direct interaction pattern of referent honorifics between speaker and interlocutor (Adapted from Lee \& Ramsey, 2000)

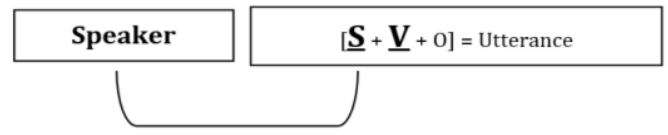

Figure 3. Indirect interaction pattern of referent honorifics without interlocutor, narrated by a speaker (Adapted from Lee \& Ramsey, 2000)

1. Referent honorifics of kinship Referent honorifics of family kinship Source : Kali ini dia berhenti di text tempat perempuan lain yang terlihat lebih tua dibanding dirinya. "Nyi, masih ada kerjaan" tanya Simbok.

Target : The time she stopped at text the stall of an older woman. "Ma'am, do you need any work done?" Simbok asked.

It shows Simbok as an indirect actor with direct conversation. It means that she is a mother whom looking for a job in the market.

2. Referent honorifics of personal pronoun

Source : "Enak saja, nyebut aku text sundal. Sampeyan sendiri yang tidak bisa ngladeni suami. Bukan suami sampeyan mau kawin sama aku."

Target : "Don't call me a whore. text You're the one that can't take care of your husband. It's not my fault that he wants to marry me."

It shows second personal pronoun in madya speech level because this condition is semi-formal so that chosen word so appropriate to greet.

3. Referent honorifics of non-kinship a) Referent honorifics of general society

Source : "Sedulur - sedulur, si text Iyem ini sundal. Suami orang direbut juga". Teriak Yu Parti dengan penuh amarah.

Target : "Everybody, Iyem text here is a whore." She's a husband stealer. Yu Parti yelled in anger.

It shows the intimate relationship among others, sedulur sedulur is close greeting in general society for growing nice conversation.

b) Referent honorifics of occupational Source : Keesokan harinya, text pagi-pagi sekali $\underline{\text { Pak }}$ $\underline{\mathrm{RT}}$ datang ke rumah kami

Target : The next day, very text early in the morning, the neighborhood unit chief came to our house.

It shows a greeting for a man who works as a village leader, namely Pak RT. Additional Pak after RT is applied as an honorifics culture in Java Island although the interlocutor, of course, has a name, it is highly polite adding Pak or Mister for a person in charge like the chief or leader in the village.

c) Referent honorifics of religion

Source : Masa aku yang sejak text kecil diajari nyuwun pada Mbah Ibu Bumi Bapa Kuasa tiba-tiba harus menghentikan semuanya.

Target : I had been taught to text workship Gusti, so how could I suddenly be expected to stop?.

It shows Javanese term of God with "Mbah Ibu Bumi Bapa Kuasa," the term in '80s to particular adherents. For them, by praying to it marks their religion. 
d) Referent honorifics of local custom Source : Dua makam di text kompleks itu dianggap keramat, yaitu makam Eyang Sujo dan Eyang Jugo.

Target : Two of the graves in text the enclosure were believed to be scared, those of Eyang Sujo and Eyang Jugo.

It shows Eyang equal with grandfather because the chosen word indicates to pass away person and deals with local custom, it is assumed that the greeting is the only one for respecting their ancestors.

4. Referent honorifics of verbs

Source : "Lik Sar wis sedo text setahun kepungkur, Cak." Ning endi ae awakmu?. Ibuk wis gak ono. Ibuk wis mati.

Target : "Lik Sar died a year ago, text Cak. Where have you been?"My mother was gone. She was dead.

It shows the madya speech level of pass away. The most polite is "tilar dunyo," based on that situation among relatives. The chosen word is so appropriate.

\section{c. By-Stander honorifics}

Lee (2000: 216) stated that by-stander honorifics was a homage to object viewed from subject and object within a conversation, without involving speaker. The use of "without involving speaker" term, not the absolute rule. It was caused that subject of conversation able to see from the first person as a speaker and second person as an utterance subject. Furthermore, contact of speaker and object could also be considered in the usage of honorifics forms to object based on utterance interaction context. In the interaction, subject and object were not interlocutors; they were only narrated as people were involvement. The interaction was patterned below:

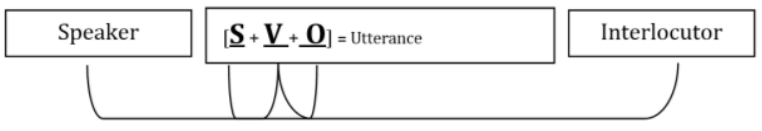

Figure 4. Interaction Pattern of By-Stander Honorifics (Adapted from Lee \& Ramsey, 2000)

1. By-Stander honorifics of kinship

By-Stander honorifics of relative kinship

Source : "Ooh... itu teman saya text dari Surabaya. Dia datang melayat Kang Teja."

Target : "Ooh... that's a friend of text mine from Surabaya. He came for Teja's funeral."

It shows Kang is a brother, it is categorized in relative because he is interlocutor husband, and she interacts with her neighbor.

2. By-Stander honorifics of personal pronoun

Source : Sambil menunggu orang text tersebut, Jali mengambilkanku makan dan minum. Katanya, beliau akan pulang setelah zuhur.

Target : The Habib would arrive text after zuhur, I was told. Jali brought me something to eat and drink.

It shows third personal pronoun, "beliau" is an honor pronoun for a person who has a big contribution to society, religion, and so on.

3. By-Stander honorifics of non-kinship

a) By-Stander honorifics of general society

Source : Orang - orang bilang text itu pasti Mbah Soleh, imam di masjid. Dia pasti yang nyoblos Partai Islam.

Target : People said that one text of them must have been old Man Sholeh, the imam at the mosque. It must 
have been him who voted for the Islamic party.

It shows "Mbah" is equal with grandfather, Javanese culture has assumed it as a general society to greet the oldest person in the community.

b) By-Stander honorifics of occupational

Source : Tentara - tentara itu text makin tak sabar. Mereka mendatangi Pak Tikno tiap hari. Pak Lurah dan Pak Camat juga turun tangan.

Target : The soldiers grew text impatient. They came to see Mr. Tikno every day. The ward chief and the subdistrict chief also got involved.

It shows that a greeting for a man who works as a village leader, namely Pak Lurah and Pak Camat. Additional Pak after Lurah and Camat is applied as an honorifics culture in Java Island although the interlocutor, of course, has a name, it is highly polite adding Pak or Mister for a person in charges like the chief or a leader in the village.

c) By-Stander honorifics of religion

Source : "Nduk, terserah apa text penginmu. Yang penting, coba nyuwun sama Mbah Ibu Bumi Bapa Kuasa. Semua kejadian hanya terjadi kalau Dia yang menginginkan".

Target : "Nduk, it is up to you text what you want to do. What's important is that you ask your creator. Things only happen if He wills it"
It shows Javanese term of God with "Mbah Ibu Bumi Bapa Kuasa," the term in the '80s to particular adherents. For them, by praying to it marks their religion.

d) By-Stander honorifics of local custom

Source : Orang-orang Gerupuk text sering datang ke desa itu. Di sana mereka biasa mendengarkan ceramah dari para tuan guru.

Target : The Gerupuk text villagers often went there to listen to the Tuan Guru preach.

It shows a call for a respected person because he has a good track record for handling society. Therefore, the tuan guru is a greeting for the teacher as logrolling.

\section{d. Absolute honorifics}

Farghal and Shakir (1994: 241) argued that it referred to contact of interactors (speaker, interlocutor, and also object of utterance) and their social activities. The high line was differences of formality and informality framing the contact of interactors "role and particular situation." There was a certain expression that the actor had to adapt his or her social interaction. Absolute honorifics was exclusively limited to someone or something admitted to the social and title of the class, such as "Your Honour," "Professor," "Oh God," and so on. Absolute social honorifics required authorized recipients for whom these titles were reserved. Furthermore, absolute social honorifics might be hugely explained to represent phenomena that were used for social aims such as greetings, "assalamualaikum," "ahlan wasahlan"

1. Absolute honorifics of non-kinship Absolute honorifics of religion

Source text : Sepanjang jalan, sesekali ada yang selawatan, menyanyikan lagulagu

yang 


\begin{tabular}{|c|c|c|}
\hline & & $\begin{array}{l}\text { mengagungkan } \\
\text { Gusti Allah. }\end{array}$ \\
\hline Target text & : & $\begin{array}{l}\text { All along the way, } \\
\text { we kept shouting } \\
\text { "Allahu Akbar!" }\end{array}$ \\
\hline & & $\begin{array}{l}\text { There were also } \\
\text { songs of praise to } \\
\text { the Almighty. }\end{array}$ \\
\hline
\end{tabular}

It shows a simple greeting of Islam religion, Gusti Allah is a mark that Moeslem greets him politely.

Source : "Assalamualaikum, Pak..." text sapa Maryam pelan.

Target : "Assalamualaikum, Sir..." text said Maryam softly.

It shows the habitual action among Moslems when they meet or in the last of mandatory pray.

\section{CONCLUSION}

Greetings and verbs of Okky Madasari Novel (Entrok, 86, Maryam, Pasung Jiwa, and Kerumunan Terakhir) successfully deliver them into the honorifics expression by integrating sociolinguistics as an appropriate approach. Addressee honorifics well integrate into all kinds of them, and they are in the kinship of family and relative, second personal pronoun, non-kinship of general society, occupational, religion, and local custom, as well as a verb. Furthermore, referent honorifics develops in almost kinds of them; they are kinship of family, second personal pronoun, non-kinship of general society, occupational, religion, and local custom, as well as a verb. While by-stander honorifics flies in half part of them, they are kinship of relative, third personal pronoun, non-kinship of general society, occupational, religion, and local custom. However, absolute honorifics consistently synergies with one part of them, it is religion. Therefore, this study successfully examines two elements of sociolinguistics by delineating indigenous languages, Javanese, and national language, Indonesian, to be a beautiful language.

To the further researcher is expected to learn and comprehend more about its detail of greetings and verbs, as well as in finding a new theory of them for integrating with honorifics expression into large study either applied linguistics or translation major.

\section{REFERENCES}

Aslinda, dkk. 2000. Kata Sapaan Bahasa Minangkabau di Kabupaten Agam. Jakarta: Pusat Bahasa Depdiknas.

Braun, Friederike. 1988. Terms of Address: Problems of Patterns and Usage in Various Languages and Cultures (Edited by Joshua A. Fishman). Berlin: Mouton de Gruyter.

Brown, Penelope \& Levinson, Stephen. 1978. "Universals in Language Usage." In: E.N.Goody (ed.), Questions and Politeness: Strategies in Social Interaction, Cambridge: Cambridge University Press, pp 56-289.

Chafe, Wallace L. 1970. Meaning and the Structure of Language. Chicago: The University of Chicago Press.

Comrie, B. 1976. Linguistic Politeness Axes: Speaker-Addressee, Speaker-Referent, Speaker - By Stander. In: Pragmatic Microfiche, 1.7: A3. University of Cambridge, Dept. of Linguistics.

Cook, Walter A.A. 1979. Case Grammar: Development of the Matrix Model (1970-1978). Washington D.C.: Georgetown University Press.

Djatmika. 2015. Kualitas Keterampilan Berbahasa Jawa Penutur Belia di Surakarta: Sebuah Fenomena Pemerolehan Bahasa. Prosising International Seminar of Language Maintenance 
and Shift V ISSN 2088-6799 hlm. 257-261. Semarang: Universitas Diponegoro dan Balai Bahasa Provinsi Jawa Tengah.

Ervin-Tripp, S.M. and A. Dill. 1973. Language Acquisition and Communicative Choice: Essays". Palo Alto, CA: Stanford University Press.

Farghal, M. dan Shakir, A. 1994. Kin Terms and Titles of Address as Relational Social Honorifics in Jordanian Arabic. In: Anthropological Linguistics, 36, pp 250-253

Fasold, Ralph. 1994. The Sociolinguistics of Society. Oxford: Basil Blackwell.

Halliday, M.A.K dan Ruqaiya Hasan. 1992. Bahasa, Konteks dan Teks. Yogyakarta: Gajah Mada University Press

Indrayanto, Bayu. 2010. Fenomena Tingkat Tutur dalam Bahasa Jawa Akibat Tingkat Sosial Masyarakat. Magistra No. 72 th XXII Juni 2010 ISSN 0215-9511.

Kaswanti Purwo, Bambang. 1989. "Tata Bahasa Kasus dan Valensi Verba" dalam Kaswanti Purwo, Bambang, peny. 1989a PELLBA II. Yogyakarta: Yayasan Kanisius, hlm. 1-23.

Khristanto. 2016. Saat Kesopanan Melintas Batas: Ulasan Teks Terjemahan Multibahasa dari Perspektif Sosiopragmatik. Prosiding Seminar Nasional Prasasti (Pragmatik: Sastra dan Linguistik) hal. $104-109$.

Kridalaksana. 1978. "Second Participant in Indonesia Address" dalam Language Sciences. Jakarta: PT. Gramedia Pustaka Utama.

Lee and Ramsey. 2000. The Korean Language. New York: State University of New York Press.

Lincoln, Y.S. \& Guba, E.G., 1985. Naturalistic Inquiry. Beverly Hills: Sage Publication.

Madasary, Okky. 2012. 86. Jakarta: PT Gramedia Pustaka Utama.

Madasary, Okky. 2013. 86 terjemahan dari 86 penerjemah Nurhayat Idriyatno Mohamed. Jakarta: PT Gramedia Pustaka Utama.

Madasary, Okky. 2013. The Outcast terjemahan dari Maryam penerjemah Nurhayat Idriyatno Mohamed. Jakarta: PT Gramedia Pustaka Utama.

Madasary, Okky. 2016. Kerumunan Terakhir. Jakarta: PT Gramedia Pustaka Utama.

Madasary, Okky. 2010. Entrok. Jakarta: PT Gramedia Pustaka Utama

Madasary, Okky. 2013. Maryam. Jakarta: PT Gramedia Pustaka Utama.

Madasary, Okky. 2013. Pasung Jiwa. Jakarta: PT Gramedia Pustaka Utama.

Madasary, Okky. 2014. Bound terjemahan dari Maryam penerjemah Nurhayat Idriyatno Mohamed. Jakarta: PT Gramedia Pustaka Utama.

Madasary, Okky.. 2011. The Years of Voiceless terjemahan dari Entrok penerjemah Nurhayat Idriyatno Mohamed. Jakarta: PT Gramedia Pustaka Utama.

Madasary, Okky.. 2017. The Last Crowded terjemahan dari Kerumunan Terakhir penerjemah Nurhayat Idriyatno Mohamed. Jakarta: PT Gramedia Pustaka Utama. 
Moeliono, Anton M. 1985. Pengembangan dan Pembinaan Bahasa: Ancangan Alternatif di dalam Perencanaan Bahasa. Jakarta: Djambatan.

Munawaroh, Siti, dkk. 2015. Degradasi Penggunaan Bahasa Jawa Krama pada Siswa Kelas 6 SDN II Dawungan, Kec. Masaran, Kab. Sragen. Seminar Nasional PIBSI XXXVII hal. 198-210. Yogyakarta: Universitas Sanata Dharma.

Pateda, Mansoer. 1987. Sosiolinguistik. Bandung: Angkasa.

Pratiwi. Destantri Melia, dkk, 2009. Analisis Wacana Keluhan Bahasa Jawa: Studi warga Desa Bangsri Kecamatan Purwantoro dan Wonogiri. Surakarta: Fakultas Keguruan dan Ilmu Pendidikan Universitas Muhammadiyah Surakarta.

Prayogo, Hari, dkk, 2015. Tingkat Tutur Penggunaan Bahasa Jawa Siswa SMPN 1 Wonosari Kajian Eksistensi dan Idialek. Seminar Nasional PIBSI XXXVII hal. 111-118. Yogyakarta: Universitas Sanata Dharma.

Purwitosari, Anjar. 2010. Analisis Wacana Puisi Jawa dalam Harian Solo Pos Edisi Januari Faebruari 2010. Skripsi. Surakarta: Fakultas Keguruan dan Ilmu Pendidikan Universitas Muhammadiyah Surakarta.

Saleem Al-Ni'aymi, Hashim Sa'doon. 2007. "Honorific Expressions in Arabic and English with Reference to other Languages" pada Tikrit University Journal for Humanities Vol. 14 No. 3 April 2007: Tikrret; University of Tikrit College of Education Department of English.

Santosa, Riyadi. 2017. Metode Penelitian Kualitatif Kebahasaan. Surakarta: UNS Press.

Sasangka, Sry Satriya Tjatur Wisnu. 2009. Unggah - Ungguh Bahasa Jawa (Editor: Yeyen Maryani). Jakarta: Yayasan Pramalingua.

Sifianou, M. 1992. Politeness Phenomena in England and Greece: A Cross Cultural Perspective. Oxford: Clarendo Press.

Spradley, J.P. 1980. Participant Observation. New York: Holt, Rinehart, and Winston.

Sudaryanto. 1983 (disertasi 1979 yang diterbitkan). Predikat-Objek dalam Bahasa Indonesia: Keselarasan Pola-Urutan. Jakarta: ILDEP-Djambatan.

Suprapto, Djuria. 2013. Analisis Penerjemahan Kalimat Pasif Bahasa Inggris ke dalam Bahasa Indonesia pada Novel Morning, Noon And Night Karya Sidney Sheldon di Jurnal Lingua Cultura Vol.7 No.1 Mei 2013 hlm. 49-56.

Sutopo, H.B. 2002. Metode Penelitian Kualitatif. Surakarta: UNS Press.

Wardhaugh, R. 1986. Introduction to Sociolinguistics. Oxford: Basil Blackwell.

Yatim, Nurdin. 1983. Subsistem Honorifik Bahasa Makasar: Sebuah Analisis Sosiolinguistik. Ujung Pandang: Departemen Pendidikan dan Kebudayaan Direktorat Jenderal Pendidikan Tinggi Direktorat Pembinaan Penelitian dan Pengabdian.

Yin, R.K. 2002. Studi Kasus: Desain dan Metode terjemahan dari (Case Study): Design and Methods (M.D. Mudzakir, Trans.). Jakarta: Raja Grafindo Persada.

Zaman, Mochamad Nuruz, Rosyidi, M., \& Budiman, Asep. 2017. The Acceptable Indigenous and Foreign Language to The Acceptable Indonesian Language Teaching: Sociolinguistics Case 
Study on UNS Print and Copy Area Overviewed within Translation Studies. International Seminar of Sociolinguistics and Dialectology "Changes and Development of Language in Social Life" 2017. Jakarta: Universitas Indonesia. 
LiNGUA Vol. 13, No. 2, Desember 2018 • ISSN 1693-4725 • e-ISSN 2442-3823 